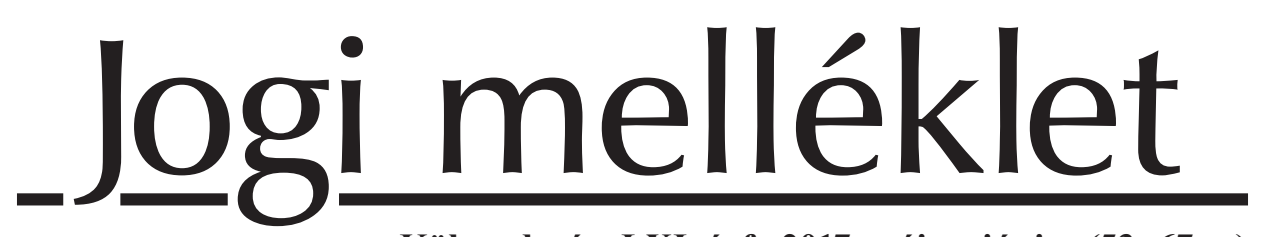

Külgazdaság, LXI. évf., 2017. május-június (53-67. o.)

\title{
A magyar nemzetközi magánjog megújulása - néhány észrevétel a nemzetközi magánjogi törvény újrakodifikálásáról, különös tekintettel a törvény általános részére
}

RAFFAI KATALIN

2017. április 4-én az Országgyülés elfogadta az új nemzetközi magánjogi törvényt, amely 2018. január 1-jétöl felváltja a jelenleg hatályos nemzetközi magánjogi törvényerejü rendeletet. A tanulmány a következö témákra fókuszál: a régi nemzetközi magánjogi törvényerejü rendelet felülvizsgálatának okai, új elméleti koncepciók megjelenése a 21. századi magyar nemzetközi magánjogban, az új nemzetközi magánjogi törvény megalkotásának közel kétéves folyamata, a törvény szerkezete és a fontosabb változások az általános kolliziós jogintézményekben a régi kódexhez képest.

Journal of Economic Literature (JEL) kód: K3; K33.

1. Bevezető gondolatok

A magyar nemzetközi magánjog forrásai a 20. század közepéig elszórtan, különböző jogszabályokban voltak jelen, amelyeket a bírói gyakorlat egészített ki, ha azt indokolta az adott jogvita rendezése. Ezt egészítették ki a főként nemzetközi kereskedelmi egyezmények és kétoldalú jogsegélyegyezmények. Az egységes jogforrási háttér hiányából fakadó nehézségek vezettek az első magyar nemzetközi magánjogi

https://oi.org/10.47630/KULG.2017.61.5-6.53

Dr. Raffai Katalin, PhD., egyetemi docens, Pázmány Péter Katolikus Egyetem, Jog- és Államtudományi Kar, Nemzetközi Magánjogi Tanszék. E-mail: raffai.katalin@jak.ppke.hu 
törvénytervezet megalkotásához 1948-ban. Szászy István jogtudós ${ }^{1}$ tervezetének elfogadását azonban az akkori politikai helyzet nem tette lehetővé. A második törvényalkotási kísérletre 1968-ig kellett várni, majd ezt követte 1970-ben a harmadik tervezet, de e tervezetek elfogadására végül nem került sor. Majdnem tízéves szünet után 1978-ban, Mádl Ferenc koncepciója alapján² elkészült a negyedik tervezet, amelyet a tervezethez képest változtatásokkal ugyan, de elfogadott a Népköztársaság Elnöki Tanácsa és az 1979. évi 13. számú törvényerejű rendelettel kihirdetésre került (a továbbiakban: Kódex). ${ }^{3}$

A jogszabály egységes szerkezetben, átfogóan szabályozza a nemzetközi magánjogi viszonyokat és a nemzetközi eljárásjogi kérdéseket, ezért a gyakorlatban meghonosodott a nemzetközi magánjogi kódex elnevezés. A Kódex a következő fejezetekből áll: I. Általános szabályok, II. Személyek, III. Szellemi alkotások joga, IV. Tulajdonjog és más dologi jogok, V. Kötelmi jog, VI. Öröklési jog, VII. Családi jog, VIII. Munkajog, IX. Joghatóság, X. Eljárásjogi rendelkezések, XI. Külföldi határozatok elismerése és végrehajtása.

\section{Az 1979. évi 13. számú tvr. felülvizsgálatának (revíziójának) indokai}

A Kódex időtállóságát és modern felfogását az bizonyítja a legjobban, hogy annak ellenére, hogy a szocializmus időszakában született, az első érdemi módosítására csak 2000-ben került sor, elsősorban európai jogharmonizációs okból. A Kódex hatékonyságát széles körü joggyakorlata is tanúsítja, különösen sokat alkalmazták nemzetközi családjogi, öröklési jogi és baleseti kártérítési ügyekben. ${ }^{4}$

2000-ben újraszabályozták a joghatóságról és a külföldi ítéletek elismeréséről és végrehajtásáról szóló fejezeteket, összehangolva az uniós joggal. 2004. május 1-jén

${ }^{1}$ Szászy István (1899-1976) nemzetközi hírü jogtudós, egyetemi tanár, bíró. Több tudományterületen is maradandót alkotott: magánjog, nemzetközi magánjog, nemzetközi eljárásjog, nemzetközi jog. Az Institut de Droit International rendes tagja, a hágai Academie de Droit International többszörös vendég előadója, az első magyar nemzetközi magánjogi törvénytervezet megalkotója. Közreműködött az egyiptomi polgári törvénykönyv tervezetének elkészítésében, a Budapesti Pázmány Péter Tudományegyetem I. Magánjogi Tanszékének tanszékvezető professzora.

${ }^{2}$ Mádl Ferenc (1931-2011) magyar jogtudós, tanszékvezető egyetemi tanár. Az európai jog, a nemzetközi magánjog és a nemzetközi kereskedelmi jog, összehasonlító magánjog nemzetközileg elismert kutatója. A Magyar Tudományos Akadémia rendes tagja, az UNIDROIT kormányzótanácsának a tagja, az ICSID választott bírája, a Magyar Köztársaság elnöke (2000-2005).

${ }^{3}$ A magyar nemzetközi magánjog fejlődéséröl lásd Mádl-Vékás: [2015], 83-87. o., Burián [2014a], 109-112. o.

${ }^{4}$ Mádl-Vékás: [2015], 85. o.

\section{JOGI MELLÉKLET • 2017/5-6}


Magyarország csatlakozott az Európai Unióhoz, amely meghatározó volt a későbbi módosítások szempontjából. Az uniós nemzetközi magánjogi rendeletek elsőbbséggel szabályozzák az uniós érintettségü nemzetközi magánjogi jogviszonyokat, és ez a Kódex későbbi módosításait is meghatározta. E módosítások célja elsősorban jogtechnikai jellegü volt, hogy az érintett témaköröknél felhívják a figyelmet arra, hogy a rendeletek mellett már csak szűk körben alkalmazhatók a törvényerejü rendelet szabályai.

A társadalmi és gazdasági viszonyok változásával az Európai Unióban nagyobb lett a nemzetközi személyi és vagyoni forgalom, aminek egyenes következménye a nemzetközi magánjogi tárgyú jogviták számának ugrásszerü növekedése. Mindez maga után vont egy intenzív jogalkotást, amelynek eredményeként a nemzetközi magánjogi jogviszonyok jelentős részét másodlagos uniós jogforrások (rendeletek) szabályozzák. ${ }^{5}$ Ezek a rendeletek beékelődtek a Kódex rendszerébe, szétfeszítették egységes rendszerét, helyenként ellentmondásokat generáltak a nemzeti szabályok és az uniós jog között. Például az uniós rendeletekben a szokásos tartózkodási hely elve a fö kapcsolóelv a nemzetközi családjogi kérdésekben, ezzel szemben a Kódex fő szabályként az állampolgárságot rendeli alkalmazni, kisegítő szabályként pedig a

5 A Tanács 44/2001/EK rendelete (2000. december 22.) a polgári és kereskedelmi ügyekben a joghatóságról, valamint a határozatok elismeréséről és végrehajtásáról (Brüsszel I rendelet).

A Tanács 2201/2003/EK rendelete (2003. november 27.) a házassági ügyekben és a szülői felelösségre vonatkozó eljárásokban a joghatóságról, valamint a határozatok elismeréséről és végrehajtásáról, illetve az 1347/2000/EK rendelet hatályon kívül helyezéséről (Brüsszel II bis rendelet). Az Európai Parlament és a Tanács 864/2007/EK rendelete (2007. július 11.) a szerződésen kívüli kötelmi viszonyokra alkalmazandó jogról (Róma II. rendelet).

Az Európai Parlament és a Tanács 593/2008/EK rendelete (2008. június 17.) a szerződéses kötelezettségekre alkalmazandó jogról (Róma I. rendelet).

A Tanács 4/2009/EK rendelete (2008. december 18.) a tartással kapcsolatos ügyekben a joghatóságról, az alkalmazandó jogról, a határozatok elismeréséröl és végrehajtásáról, valamint az e területen folytatott együttmüködésröl (Tartási rendelet).

A Tanács 664/2009/EK rendelete (2009. július 7.) a házassági ügyekben, a szülöi felelősségre vonatkozó eljárásokban, valamint a tartással kapcsolatos ügyekben a joghatóságról, valamint a határozatok elismeréséről és végrehajtásáról, továbbá a tartással kapcsolatos ügyekben alkalmazandó jogról szóló, a tagállamok és harmadik országok között létrejövő megállapodásokkal kapcsolatos tárgyalásokra és e megállapodások megkötésére vonatkozó eljárás létrehozásáról. A Tanács 1259/2010/EU rendelete (2010. december 20.) a házasság felbontására és a különválásra alkalmazandó jog területén létrehozandó megerősített együttműködés végrehajtásáról. (Róma III rendelet).

Az Európai Parlament és a Tanács 650/2012/EU rendelete (2012. július 4.) az öröklési ügyekre irányadó joghatóságról, az alkalmazandó jogról, az öröklési ügyekben hozott határozatok elismeréséről és végrehajtásáról, valamint az öröklési ügyekben kiállított közokiratok elfogadásáról és végrehajtásáról, valamint az európai öröklési bizonyítvány bevezetéséről (Öröklési rendelet). A Tanács 1215/2012/EU rendelete (2012. december 12.) a polgári és kereskedelmi ügyekben a joghatóságról, valamint a határozatok elismeréséről és végrehajtásáról (új Brüsszel I rendelet). 
lakóhely elvét, és csak ezek hiányában a szokásos tartózkodási helyet. A rendeletek és a Kódex divergáló szabályai megnehezítették a magyar jogalkalmazást.

A Hágai Nemzetközi Magánjogi Konferencia - amelynek Magyarország már a kezdetektől alapító tagja volt - keretében számos nemzetközi egyezményt is elfogadtak, amelyek nagy részéhez Magyarország is csatlakozott. ${ }^{6}$ Éppen ezért a jogforrások rendszerében a multilaterális egyezmények jelentősége megnőtt, a jogalkalmazás számára pedig egyre nehezebb lett átlátni, hogy ebben a hármas struktúrában mi is az alkalmazandó jog: a magyar jogszabályt kell alkalmazni, vagy egy nemzetközi egyezményt, esetleg egy uniós rendeletet. Bizonyos esetekben egy adott tényállás kapcsán akár két-három féle jogforrás is releváns lehet, ami elbizonytalaníthatja a jogalkalmazót.

A nemzetközi magánjogi reformot generáló uniós és nemzetközi jogi hatások mellett figyelembe kellett venni a nemzeti magán anyagi és eljárásjog változásait is. Az utóbbi néhány évben a magyar jogrendszer magánjoga teljes megújuláson ment keresztül: megszületett az új polgári törvénykönyv ${ }^{7}$ és az új polgári perrendtartási

${ }^{6}$ Magyarország főként eljárási és családjogi egyezményekhez csatlakozott, ezek a következők: A polgári eljárásra vonatkozó, Hágában az 1954. évi március hó 1. napján kelt nemzetközi egyezmény (kihirdette az 1966. évi 8. tvr.); végrehajtási jogszabály: 4/1966. (VI. 15.) IM rendelet.

A gyermektartási kötelezettség tárgyában hozott határozatok elismeréséről és végrehajtásáról Hágában, az 1958. évi április hó 15-én aláírt egyezmény (kihirdette az 1965. évi 7. tvr.).

A külföldön felhasználásra kerülö közokiratok diplomáciai vagy konzuli hitelesítésének (felülhitelesítésének) mellőzéséről Hágában 1961. október 5. napján kelt egyezmény (kihirdette az 1973. évi 11. tvr).

A polgári és kereskedelmi ügyekben keletkezett bírósági és bíróságon kívüli iratok külföldön történő kézbesítéséről szóló Hágában, 1965. november 15. napján kelt Egyezmény (kihirdette a 2005. évi XXXVI. törvény).

A polgári és kereskedelmi ügyekben külföldön történő bizonyítás felvételröl szóló Hágában, 1970. március 17. napján kelt egyezmény (kihirdette a 2004. évi CXVI. törvény).

A Gyermekek Jogellenes Külföldre Vitelének Polgári Jogi Vonatkozásairól szóló, Hágában 1980. október 25-én kelt egyezmény (kihirdette az 1986. évi 14. tvr.); Végrehajtási jogszabály: 7/1988. (VIII. 1.) IM rendelet.

A szülői felelősséggel és a gyermekek védelmét szolgáló intézkedésekkel kapcsolatos együttműködésről, valamint az ilyen ügyekre irányadó joghatóságról, alkalmazandó jogról, elismerésről és végrehajtásról szóló, Hágában, 1996. október 19-én kelt Egyezmény (kihirdette a 2005. évi CXL. törvény).

A gyermekeknek a nemzetközi örökbefogadások terén való védelméröl és az ilyen ügyekben történő együttműködésről szóló, Hágában, 1993. május 29. napján kelt Egyezmény (kihirdette a 2005. évi LXXX. törvény).

A gyermektartás és a családi tartások egyéb formáinak nemzetközi behajtásáról szóló, 2007. november 23-i hágai egyezmény (kihirdette a Tanács 2011/432/EU határozata).

A tartási kötelezettségekre alkalmazandó jogról szóló, 2007. november 23-i hágai jegyzőkönyv (kihirdette a Tanács 2009/941/EK határozata.

7 2013. évi V. törvény a Polgári Törvénykönyvröl.

56 JOGI MELLÉKLET • 2017/5-6 
kódex. ${ }^{8}$ Tekintettel a civiljogi jogalkotás megújulására, szükségszerủ volt, hogy ehhez igazodjon a nemzetközi magánjog is, hogy fogalomrendszere összhangba kerüljön a magánjogi kódexek fogalomrendszerével.

Végül, de nem utolsósorban meg kell említeni, hogy az utóbbi években a kelet-közép-európai (volt szocialista) államokban a nemzetközi magánjog szabályainak átfogó reformja kezdődött el Bulgáriában, ${ }^{9}$ Lengyelországban, ${ }^{10}$ Romániában, ${ }^{11}$ Csehországban, ${ }^{12}$ amely aktusok szintén inspirálóan hatottak a magyar jogalkotásra.

\section{A törvényalkotás folyamata}

A magyar nemzetközi magánjogi jogirodalomban Magyarország uniós csatlakozását követően elemzések születtek arról, hogy a másodlagos uniós jogi instrumentumok hogyan rendezik át és idézik elö a magyar nemzetközi magánjog töredezettségét. Az újabb és újabb uniós rendeletek megszületése lassan megérlelte a gondolatot, hogy időszerü lenne a magyar nemzetközi magánjog átfogó reformja. 2014 végén a kormányban felmerült egy új nemzetközi magánjogi kódex megalkotásának a terve. Ennek a folyamatnak a következő állomása volt egy 2015 februárjában tartott nemzetközi magánjogi konferencia, amelyen részt vettek a tudományos élet képviselői, akik egységesen úgy foglaltak állást, hogy időszerủ rekodifikálni a magyar nemzetközi magánjogot. ${ }^{13}$

2015. május 27-én ${ }^{14}$ megjelent a Magyar Közlönyben a Kormány 1337/2015. (V. 27.) korm. határozata az új nemzetközi magánjogi szabályozás kodifikációjáról és a Nemzetközi Magánjogi Kodifikációs Bizottság felállításáról. A kormányhatározat elrendelte a nemzetközi magánjogról szóló 1979. évi 13. törvényerejủ rendelet korszerüsítésére irányuló munkálatok megkezdését. A célkitűzés egy korszerü, a nemzetközi magánjog uniós és nemzetközi szintủ szabályozásával összhangban álló új nemzetközi magánjogi törvény megalkotása volt. Ennek keretei között felállításra

8 2016. évi CXXX. törvény a polgári perrendtartásról.

${ }^{9}$ Bulgarian Private International Law Code 2005.

${ }^{10}$ Act of 4 February 2011 Private International Law.

${ }^{11}$ CARTEA VII - Dispozitii de drept international privat Codul Civil. Noul Cod Civil republicat 2011. Legea 287/2009 privind Codul civil.

12 91[/2012] Act as of 25 January 2012 on Private International Law.

${ }_{13}$ ELTE Állam- és Jogtudományi Karon 2015. 02. 06.-án tartott Nemzetközi Magánjogot Oktatók XI. Országos Konferenciája, „A nemzetközi magánjog kodifikációjának hazai és európai uniós távlatai".

${ }^{14}$ Magyar Közlöny, 2015. évi 72. szám. 
került a Nemzetközi Magánjogi Kodifikációs Bizottság, melynek tagjait az igazságügyminiszter által felkért, a nemzetközi magánjog szakterületével professzionálisan foglalkozó egyetemi oktatók, ügyvédek, bírák, minisztériumi tisztviselők képezték.

A kormányhatározat az új nemzetközi magánjogi törvény megalkotására összeállított egy ütemtervet, mely szerint:

- a törvény koncepciójának kidolgozásának határideje 2015. november 30.

- a koncepcióról szóló szakmai, illetve társadalmi viták lefolytatása: 2016. január 31.

- a normaszöveg tervezetének kidolgozása a koncepció alapján 2016. november 30 .

A Kodifikációs Bizottság első ülésére 2015 júniusában került sor, ahol a jogszabályalkotási munka ütemterve mellett megállapodás született a törvénykoncepció alapjául szolgáló ún. háttértanulmányok kidolgozásának szükségességéröl is. A háttértanulmányok elkészülése és megvitatása után november végére elkészült a nemzetközi magánjogi törvény koncepciója. ${ }^{15}$ A normaproblematika kidolgozása a Kodifikációs Bizottság tagjaiból alakított munkabizottságokban történt. A munkabizottságok - személyek joga, vagyonjogi, családjogi és a joghatóság, elismerés és végrehajtás, az eljárásjog és a felszámolás kérdéseivel foglalkozó munkabizottságok - a tematikus összeállításnak megfelelően foglalkoztak a megalkotandó jogszabály kidolgozásával, amelyek a Kodifikációs Bizottság előtt kerültek megvitatásra. 2016 novemberére elkészült a normaszöveg az indokolással. A szakmai és társadalmi szervezetekkel történt egyeztetések befejezése után 2017 februárjában az igazságügyi miniszter benyújtotta a T/14237. számú törvényjavaslatot a nemzetközi magánjogról, 2017. április 4-én pedig a parlamentben elfogadták a 2017. évi XXVIII. számú törvényt a nemzetközi magánjogról (a továbbiakban: Nmj. tv.). Az új nemzetközi magánjogi törvény, összhangban az új polgári perrendtartásról szóló a polgári perrendtartásról szóló 2016. évi CXXX. törvénnyel, 2018. január 1-jén lép hatályba.

${ }^{15}$ A háttértanulmányok Berke Barna - Nemessányi Zoltán (szerk.) [2016]: Az új nemzetközi magánjogi törvény alapjai - Kodifikációs előtanulmányok I-II. Budapest, HVGORAC, kötetben kerültek kiadásra. 


\section{Az új nemzetközi magánjogi törvény szerkezete}

A Kodifikációs Bizottságban a törvény szerkezete tekintetében több koncepció is felmerült. Az egyik alternatíva szerint a törvény szerkezetének tükröznie kellene a jogalkalmazási folyamatot, ezért célszerủ lenne az elején a bevezető rendelkezések után elhelyezni a joghatósági szabályokat, majd azután az általános és különös részt, végül az eljárási, elismerési és végrehajtási szabályokat. Felmerült az a lehetőség is, hogy tematikusan, az egyes fejezetek a jogviszonyhoz igazodóan a joghatósági - alkalmazandó jogi - elismerési és végrehajtási szabályokra tagolódjanak. E lehetőség végül elvetésre került, mert nehézkessé tette volna a törvény struktúráját. Végül a jelenleg hatályos Kódex szerkezeti rendszerét tartotta meg a Kodifikációs Bizottság, amelyet néhány kisebb módosítással egészített ki. A módosításokra a Ptk. szerkezetéhez való hozzáigazítás céljából került sor: a gondnokság szabályai átkerültek a családjogi részből a személyes jogba, a családjogi fejezet a személyek után, míg a szellemi tulajdonjog a dologi jogi rész után következik. ${ }^{16}$ Kikerültek a törvényböl azok a korábban önálló fejezetek, amelyek az uniós jog hatálya alá kerültek, mint például a munkajogi fejezet, amely a Róma I. rendelet részét képezi. Változott a joghatóságról, eljárásról, elismerés és végrehajtásról szóló rész is: az eljárásjogi rendelkezések után az állam immunitásával összefüggő szabályok kaptak helyet, azt követik a joghatósági szabályok, és végül a külföldi határozatok elismerésére és végrehajtására vonatkozó rendelkezések zárják ezt a részt.

Többszöri változtatást követően végül az új törvény tizenkét fejezetből áll, amelyek a következöképpen követik egymást: I. Általános rendelkezések, II. Személyek, III. Családjog, IV. Élettársak, bejegyzett élettársak, V. Dologi jog, VI. Szellemi tulajdonjog, VII. Kötelmi jog, VIII. Öröklési jog, IX. Eljárásjogi rendelkezések, X. Joghatóság, XI. Külföldi határozatok elismerése és végrehajtása, XII. Záró rendelkezések.

\section{Az új nemzetközi magánjogi törvény általános része, különös tekintettel a változásokra}

Az Európai Unió Mủködéséről Szóló Szerződés 81. cikkéből fakadó felhatalmazás alapján került sor számos nemzetközi magánjogi tárgyú európai uniós (ko-

${ }^{16}$ A Ptk.-val és a hatályos Kódexszel történő összehangolás igényéről lásd: Vékás [2016], 17. o. 
rábban európai közösségi) rendelet megalkotására. Az uniós rendeletek általános hatályú, kötelezően és közvetlenül alkalmazandó másodlagos jogforrások, amelyek a tagállami nemzetközi magánjogi jogszabályokhoz képest elsőbbséget élveznek. Ez azt is jelenti, hogy a rendelet tárgyi hatálya alá eső nemzeti szabályokat nem lehet fenntartani, sőt az adott kérdéskör tekintetében új tagállami szabályokat sem lehet alkotni. Az Amszterdami Szerződés hatályba lépése óta eltelt időszakban az uniós másodlagos nemzetközi magánjogi tárgyú jogforrások látványos elöretörése számos területen (kötelmi, családi, öröklési kollíziós jog, valamint polgári és kereskedelmi, családi, tartási, öröklési joghatósági és eljárásjog) kiszorította a tagállami szabályozást. Nemzeti jogalkotási hatáskörbe kizárólag azok a kérdések tartoznak, amelyek tekintetében a rendeletek kizárják a hatályukat, esetleg nincsenek vonatkozó rendelkezések (joghézag), illetve amelyeket (még) nem szabályoz rendelet. Az új törvény tehát az uniós nemzetközi magánjogi instrumentumok és a nemzetközi megállapodások által nem szabályozott kérdések rendezésére fókuszál. Ezt a törvény az I. fejezet Általános rendelkezések körében ki is mondja: a 2. § értelmében a törvény rendelkezéseit olyan kérdésekben kell alkalmazni, amelyek nem tartoznak az Európai Unió általános hatályú, közvetlenül alkalmazandó jogi aktusa vagy nemzetközi szerződés hatálya alá.

A nemzetközi magánjogi jogviszonyok sajátossága, hogy a tényállásban releváns nemzetközi elem van, amely a tényállást két vagy több állam jogszabályaihoz kapcsolja, és a nemzetközi magánjogi szabályok feladata eldönteni, hogy az egymással versengő jogok közül melyiket kell alkalmazni. A nemzetközi magánjog válasza hasonló esetekre az ún. közvetett szabályozáson keresztül történik, amely a kapcsoló tényezők/elvek segítségével jelöli ki, hogy melyik jog lesz végül alkalmazandó. Hagyományosan a nemzetközi magánjog egy értéksemleges jog, amely egyfajta automatizmust követve kijelöli, hogy melyik állam joga lesz végül irányadó. Ez a merev rendszer nem veszi figyelembe a felek egyedi körülményeit, azt, hogy egy másik jog alkalmazása igazságosabb eredményre vezethetne, vagy hogy a gyengébb fél védelme melyik jog alkalmazását indokolná. A Kódex - összhangban a hagyományos nemzetközi magánjogi felfogással - ezt a merev szemléletet követte. A 20. század második felétől egyre bonyolultabbak és komplexebbek lettek a nemzetközi magánjogi viszonyok, amelyek specializáltabb jogalkalmazást tettek indokolttá. Mindezek azzal a következménnyel is jártak, hogy a hagyományos szemlélet (a korábbi merev kapcsolóelvek) alkalmazása nem feltétlenül szolgálta a nemzetközi magánjog egyik alapvető célkitüzését, a nemzetközi döntési harmóniát. 
Az uniós jog beékelődése a tagállami nemzetközi magánjogi szabályokba szintén behatárolta a változás irányát, mert a divergencia elkerülése érdekében célszerü összhangba hozni a nemzeti nemzetközi magánjogban alkalmazott kapcsolóelveket az uniós rendeletekben fellelhetőkkel. Másrészt a tagállami hatáskörben maradó jogszabályoknak is összhangban kell lenniük az uniós alapjogokkal (diszkrimináció tilalma, mozgás, letelepedés, szolgáltatás szabadsága stb.), és Európai Bíróságra hárul a feladat, hogy e szabályok uniós joggal való összeegyeztethetőségét megvizsgálja.

Az uniós rendeletek - a Hágai Nemzetközi Magánjogi Konferencia által megalkotott multilaterális egyezmények nyomvonalán haladva - szakítottak a korábbi merev szemlélettel, és jóval rugalmasabb megközelítést alkalmaznak: az állampolgárság helyett dominál a szokásos tartózkodási hely elve, egyre nagyobb lehetőséget adnak a felek autonómiájának (jogválasztás), a gyengébb fél védelmének (imperatív szabályok, speciális joghatósági szabályok) és a bírói mérlegelésnek (a legszorosabb kapcsolat elve).

Ezt a változást követi az új magyar nemzetközi magánjogi törvény is, a régi merev szabályozással szemben sokkal rugalmasabb, nagyobb teret enged a felek jogválasztásának, hogy ök dönthessék el közös akaratelhatározással, hogy mi az alkalmazandó jog, és szélesebb lehetőséget biztosít a bírói mérlegelésnek is. Az egész törvényt átható újdonság a merev, csak egy jogrendszer irányába mutató szabályok oldása.

Az alábbiakban röviden ismertetjük az általános rész főbb változásait, különös tekintettel azokra az rendelkezésekre, amelyeket a Kódex nem szabályozott.

Az I. fejezet Általános részében találjuk a törvény hatályát, az értelmező rendelkezéseket, a minősítést, a vissza- és továbbutalást, a több jogrendszerrel rendelkező államokra vonatkozó szabályozást, a külföldi jog alkalmazásának kérdéseit, a jogválasztást, az általános kitérítő klauzulát, az általános kisegítő szabályt, a közrendi záradékot, az imperatív szabályokat és a statútumváltást.

Az Nmj. tv. általános része egy újítással indít, az uniós rendeletek szerkezeti felépítéséhez hasonlóan a törvény elején, az Értelmező rendelkezések című részben találjuk azoknak az alapfogalmaknak a definícióját, amelyek a törvény több részében is előfordulnak és amelyek értelmezését a jogalkotó kiemelten fontosnak tartja. Ilyen bevezető részt a hatályos Kódexben nem találunk. Az új törvény a 3. §-ban három fogalmat definiál: hogyan kell értelmezni e törvény kontextusában a bíróság, a szokásos tartózkodási hely, valamint a lakóhely fogalmát.

A bíróság alatt kell érteni az összes hatóságot, amelyek a törvény hatálya alá tartozó ügyekben hatáskörrel rendelkeznek. 
A szokásos tartózkodási hely az egyik leggyakrabban előforduló kapcsolóelv mind az uniós rendeletekben, mind a multilaterális nemzetközi magánjogi egyezményekben. Ennek ellenére sem a rendeletek, sem a Hágai Egyezmények nem definiálják. Az Európai Unió Bírósága számos döntésében irányadó szempontokat adott a szokásos tartózkodási hely meghatározására a határon átnyúló jogviszonyok körében. ${ }^{17}$

Az új törvény a jogalkalmazás megkönnyítése érdekében definiálja a szokásos tartózkodási helyet, amelyről egyértelmüen megállapítható, hogy az Európai Unió Bírósága döntéseiböl körvonalazódó fogalom alapulvételével történt. Az új törvény 3. § b) pontja szerint a szokásos tartózkodási hely az a hely, ahol a személy életvitelének a tényleges központja van, ezt a központot pedig a személy szándékának és a tényeknek az alapulvételével kell meghatározni. A Nmj. tv. a szokásos tartózkodási hely kapcsolóelvének központi szerepet szánt: alkalmazza a személyes jogban, a személyhez füződő jogok védelménél, a családjogban, az élettársi kapcsolatoknál, megteremtve ezáltal a korábban hiányzó összhangot a magyar és az uniós jog között.

A lakóhely fogalmát az új nemzetközi magánjogi törvény a Brüsszel I A rendelettel összhangban elsősorban a vagyonjogi ügyekre vonatkozó joghatósági szabályok körében használja. A lakóhely azt a helyet jelöli, ahol egy személy ténylegesen lakik, méghozzá állandó jelleggel vagy a végleges letelepedés szándékával.

Változnak a minősítés (characterization, Qualifikation) szabályai is. A minősítés (4. §) során azt kell eldönteni, hogy az adott tényállás a jogrendszer keretei között milyen jogi kategóriába sorolódik be, és e szerint milyen kapcsolóelvet kell alkalmazni. Például kérdéses lehet, hogy a túlélő házastárs haszonélvezeti joga az ingatlanon a házassági vagyonjog vagy az öröklési jog körébe tartozik-e. A fő szabály változatlan maradt, mind a régi, mind pedig az új szabályozás az eljáró fórum joga (lex fori), vagyis a hazai jog szerinti minősítést tekinti mérvadónak. Problémát jelenthet a hazai jogban ismeretlen jogintézmények minősítése, hiszen ez a hazai jog alapján nem lehetséges. Például abban az esetben, amikor a felek az általuk kötött szerződésre a német jogot kötötték ki, ezért a szerződésre a magyar jogban nem ismert ún. Dienstvertrag (BGB 611-630. §) szabályait kellett alkalmazni. A problémát az okozta, hogy ezt a szerződéstípust szolgálati szerződésnek fordították, amelyet a magyar jogban munkaviszony keretei között alkalmaznak, miközben valójában egy társaság és ügyvezetője között felmerült vitát, vagyis polgári jogviszonyt kellett

${ }^{17}$ Részletesen lásd: Raffai [2016c], 48-51. o. 
elbírálni. Végül a Fővárosi Ítélőtábla a Kódex 3. § (2) bekezdése szerint ${ }^{18}$ a német jog alapján minősítette a szerződést. ${ }^{19}$ A Kódex ilyen esetekben lehetővé tette a föszabály alóli kivételt, tehát a lex causae, vagyis az alkalmazandó jog szerinti minősítést, amelyet az új törvény is megtartott. ${ }^{20} \mathrm{~A}$ jogalkotó az új törvényben tovább finomított a minősítés szabályain egy újabb kivétel beiktatásával: ha a magyar jog ugyan ismeri az adott jogintézményt, de annak funkciója vagy célja eltér a külföldi jogban betöltött céljától, funkciójától, akkor a minősítés során e külföldi jogra is tekintettel kell a minősítést elvégezni. A minősítés problematikája nemcsak a kollíziós jogban merül fel, hanem a joghatóság megállapítása, illetve a külföldi határozatok elismerése és végrehajtása vonatkozásában is, a Nmj. tv. felhívja a figyelmet, hogy a minősítés szabályait e kérdésekben is adekvátan alkalmazni kell.

A vissza- és továbbutalás (renvoi) a nemzetközi magánjog egyik legtöbb vitát kiváltó jogintézménye. A nemzetközi magánjog célja, hogy a kollíziós tényálláshoz hozzárendelt kapcsoló tényező segítségével összekapcsolja a tényállást a megfelelő jogrendszerrel, melynek azután az anyagi jogi szabályait alkalmazza. A kollíziós utalás terjedelmét főszabályként szüken kell értelmezni, vagyis a felhívott jogrendszer anyagi jogi normáit kell alkalmazni. Lehetnek olyan jogpolitikai indokok is, amikor az utalás terjedelmét tágan kell értelmezni, amely magába foglalja a felhívott jogrendszer kollíziós normáit is. ${ }^{21}$ Ez utóbbi teremti meg a vissza- és továbbutalás alkalmazásának a lehetőségét. ${ }^{22} \mathrm{~A}$ Nmj. tv.-ben jelentősen változnak a renvoi szabályai (5. §). A Kódex általános jelleggel ugyan, de kizárólag a részleges renvoit (csak a visszautalás részét) fogadja el, vagyis ha a külföldi jog a magyar jogra utal vissza, amit a szakirodalom a "hazafelé törekvés" ${ }^{23}$ egyik példájaként értékel. ${ }^{24} \mathrm{Az}$ új szabályozás szakít a korábbi megoldással, csak abban az esetben teszi lehetővé a vissza- és továbbutalást, ha az állampolgárság szerint kell megállapítani az alkalmazandó jogot. Ilyen esetben lehetővé teszi a teljes renvoit, vagyis a külföldi kollíziós jog visszautalását és egyszeri továbbutalását is figyelembe kell venni.

18 3. § (2) Ha a magyar jog valamely jogintézményt nem ismer, vagy eltérő tartalommal, más elnevezéssel ismer, és az a magyar jog szabályainak értelmezésével sem határozható meg, a jogi minősítésben a jogintézményt szabályozó külföldi jogra is figyelemmel kell lenni.

${ }^{19}$ Gpkf. II. 26.269/2008/2.

20 A minősítés szabályainak változatlanul hagyásáról lásd: Vékás [2016], 21. o.

${ }^{21}$ A vissza- és továbbutalásról részletesen lásd Burián [2016b].

${ }^{22}$ A visszautalás azt jelenti, amikor a felhívott jogrendszer nemzetközi magánjogi szabályai az eredeti állam jogára utalnak vissza, míg a továbbutalás esetén a felhívott jogrendszer szabályai egy harmadik állam jogára utalnak tovább.

${ }^{23}$ A „hazafelé törekvés” kifejezés a nemzetközi magánjogban a hazai jog indokolatlan előnyben részesítésére utal.

${ }^{24}$ Mádl-Vékás [2015], 124. o.; Burián [2016], 42. o. 
A Nmj. tv. 6. §-a egy teljesen új rendelkezést tartalmaz, amely az ún. területközi és személyközi kollízió kérdését szabályozza a több jogrendszerrel rendelkező államok körében. Vannak olyan államok, amelyeken belül több jogrendszer létezik egymás mellett, különösen ilyenek a szövetségi államok, ahol az egyes területi egységek önálló joggal rendelkeznek (például USA, Kanada), és a nemzetközi magánjogi tényállás több területi egységet is érint, ilyen esetben belső kollízió alakulhat ki. Tekintettel arra, hogy ez nem valódi nemzetközi magánjogi kollízió, ilyenkor az adott állam több területi egysége közötti összeütközés feloldására az adott állam nemzeti kollíziós szabályai szerint kell feloldani az összeütközést.

Vannak olyan államok is, ahol az államon belül más-más jog alkalmazandó a személyek különböző csoportjai vonatkozásában, ez az ún. személyközi kollízió. A vallási jogokat alkalmazó államokban (pl. Izrael vagy a muszlim államok) fordul elö, hogy a személyekre vallásuk szerint más-más jogot kell alkalmazni a személyállapottal kapcsolatos kérdésekre. Ilyenkor az adott állam kollíziós szabályai határozzák meg, hogy az adott személyre melyik jogot kell alkalmazni. Abban az esetben, ha a területközi vagy a személyközi kollízió feloldása akadályba ütközik, például nem szerezhető be a rendelkezés, vagy alkalmazásuk nem vezetne egyértelmủ eredményre, akkor annak az államnak a jogát kell alkalmazni, amely a legszorosabb kapcsolatban van a tényállással.

A külföldi jog alkalmazása tekintetében nincs lényeges változás az új törvényben, a Kódexhez hasonlóan a külföldi jogot jogkérdésként kezeli és hivatalbóli alkalmazását írja elő. Ez a szabály kiegészül egy új rendelkezéssel, mely szerint a bíróságnak a külföldi jog rendelkezéseit a külföldi jog kontextusában kell vizsgálni, figyelemmel annak külföldi jogalkalmazási gyakorlatára is. A külföldi jog tartalmának megállapítása szintén a bíróság kötelezettsége. Nincs jelentősebb változás a külföldi jog tartalmának bizonyítását illetően sem, ahogyan a Kódex, úgy az új törvény is lehetővé teszi, hogy a bíró különböző eszközöket vegyen igénybe bizonyítás céljából, mint például a felek előterjesztéseit, szakvéleményt, vagy megkeresse tájékoztatás céljából az Igazságügyi Minisztériumot is. Ha a külföldi jog tartalmát észszerű időn belül nem lehet megállapítani, a magyar jogot kell alkalmazni. A Nmj. tv. újítása, hogy számol azzal az eshetőséggel, amikor a nem ismert tartalmú külföldi joggal legszorosabb kapcsolatot mutató eset a magyar jog szerint nem bírálható el megfelelően, ilyenkor alkalmazható kisegítő jelleggel az alkalmazandó joghoz legközelebb álló külföldi jog.

A nemzetközi magánjog egyre nagyobb teret enged a felek autonómiájának, akiknek széles körben lehetősége adódik, hogy közös megegyező akarattal kiválasz- 
szák az alkalmazandó jogot. A Kódex is lehetővé tette a feleknek a jogválasztást a kötelmi jogban, de újdonság, hogy az általános részben, önálló cikkben, általános tételként rendelkezik az új törvény a felek jogválasztásáról (9. §). A törvény hangsúlyozza, hogy a jogválasztásnak kifejezettnek kell lennie - mindez összhangban van az uniós rendeletek szabályaival -, a feleknek minden kétséget kizáróan meg kell jelölni az alkalmazandó jogot. A választott jog szabályai kiterjednek a megállapodás létrejöttére és érvényességére is, de akkor is érvényesnek tekinthetö, ha megfelel a jogválasztás megkötésének a helye szerinti jog rendelkezéseinek. A felek autonómiája ugyanakkor nem vezethet harmadik személyek jogainak csorbításához.

Koncepcionális nóvumot jelent a törvény 10. §-ában szabályozott általános kitérító klauzula (escape clause, Ausweichklausel), amely szerint ha úgy ítéli meg a bíró, hogy egy másik joggal nyilvánvalóan szorosabb kapcsolatot mutat a tényállás, akkor lehetősége van ennek a jognak az alkalmazására az egyébként irányadó jog helyett. ${ }^{25}$ Ezt a felek is kezdeményezhetik, ebben az esetben a bíró mérlegeli, hogy elfogadja-e és alkalmazza a klauzulát. A kitérítö klauzulát a Kódex eredetileg csak a szerződések jogában, kisegítő kapcsolóelvként szabályozta, majd a Róma I. és Róma II. rendeletek alkalmazásával kiterjedt az egész kötelmi jogra. Általános generál klauzulaként történő szabályozása nagyobb lehetőséget ad az eljáró fórumnak, hogy mérlegelési jogkörével élve a jogviszonyhoz adekvátan kapcsolódó jogot alkalmazza. Az általános kitérítő klauzulával biztosított szabadságnak egyetlen korlátja a felek jogválasztása, ebben az esetben az általános kitérítő klauzula nem alkalmazható. Ugyancsak ide kapcsolódik az általános kisegítő szabály (11. §) kérdése, amely szintén a legszorosabb kapcsolat elvét rendeli arra az esetre, ha törvény nem tartalmaz rendelkezést e hatálya alá tartozó jogviszonyra.

A közrendi klauzula (ordre public, public policy, Vorbehaltsklausel) funkciója a nemzetközi magánjogban védelemben részesíteni a hazai jog alapvető értékrendjét és egyben elutasítani a nemzeti közrenddel ellentétes eredményre vezető külföldi szabály alkalmazását. Ilyenkor a kiesett idegen jog helyett kisegítő jogként a hazai jogot (lex fori) kell alkalmazni. A közrendi klauzula tehát egy generálklauzula szabály, amelyet a jogalkalmazó tölt ki tartalommal. ${ }^{26}$ A közrendi klauzuláról a hatályos Kódex is rendelkezik, de az új törvény a jogalkalmazó munkáját jobban segíti azzal, hogy pontosítja a közrend által védendő alapvető értékek körét, amelyekbe az alkotmányos elvek védelme is kifejezetten beletartozik (12. §). Fontos hangsúlyozni,

${ }^{25}$ Az általános kitérítő klauzulának az új törvényben történő szabályozásáról lásd: Vékás [2016], 29. o.

${ }^{26}$ Részletesen lásd: Raffai [2016a]. 
hogy kikerült a szabályozásból az a korábbi figyelemfelhívó szabály, amely az eltérő társadalmi berendezkedésen alapuló jog indokolatlan mellőzésének tilalmát mondja ki. E rendelkezés, amely magán viselte a szocialista államberendezkedés politikaiideológiai lenyomatát, mára funkcióját vesztette, ezért az új jogszabályból indokolt volt az elhagyása.

A közrendi klauzula mellett a feltétlen alkalmazást kívánó imperatív szabályok (overriding mandatory rules, Eingriffsnormen) szintén védelmi funkciót töltenek be. Ezek olyan nemzeti anyagi jogi szabályok, amelyeknek célja a közérdek védelme, és ezért ezektől a jogalkotó nem enged eltérést. Olyan anyagi jogi normák tehát, amelyek Magyarországon alapvető politikai, gazdasági és szociálpolitikai érdekeket szolgálnak, ezért nemcsak a nemzeti jogrendszerhez kötődő jogviszonyok esetén kötelező az alkalmazásuk, hanem külföldi érintettség esetén is. Ezért, ha a bíróság azt látja, a nemzetközi tényállásban felmerülö életviszonyokra a hazai jog imperatív szabályok alkalmazását írja elő, akkor nem kell kollíziós úton megkeresnie az alkalmazandó jogot, hanem helyette a kérdést automatikusan a közvetlen jogrendezést biztosító, belföldi imperatív szabály alapján bírálja el. A Kódex nem rendelkezett az imperatív szabályokról, ezt a joghézagot küszöbölte ki a Nmj. tv. 13.§-a az uniós joggal (mindenekelött a Róma I. és II. rendeletekkel) összhangban. Az új törvény lehetőséget biztosít arra is, hogy a bíróság más állam imperatív szabályait is figyelembe vegye, ha azok a tényállással szoros kapcsolatban állnak, és nélkülük a vitás tényállás nem bírálható el megfelelően.

\section{6. Összegző gondolatok}

Ahogyan azt a bevezető részben is vázoltuk, az új nemzetközi magánjogi törvény megalkotása időszerübb volt, mint valaha. A jogalkotás kereteit az uniós és a nemzetközi jogforrások szabták, de összhangba kellett hozni az új magánjogi kodifikációs eredményekkel is. Mindemellett tekintettel kellett lenni az időközben bekövetkezett új nemzetközi magánjogi irányzatokra, valamint a társadalmi változásokra is. Hogy mennyire sikerült e komplex kihívásoknak megfelelni, arra majd csak néhány év múlva kapunk választ, hiszen egy jogszabály sikeressége tekintetében mindig a joggyakorlat tud adekvát visszaigazolást nyújtani. 


\section{Felhasznált irodalom}

Burián László [2016a]: Megjegyzések a készülő nemzetközi magánjogi kódex koncepciójának a hatállyal, a szerkezettel és az általános rendelkezésekkel kapcsolatos megállapításaihoz. In: Glavanits Judit - Horváthy Balázs - Knapp László (szerk.): Az európai jog és a nemzetközi magánjog aktuális kérdései - Ünnepi tanulmányok a 65 éves Milassin László tiszteletére. Győr.

Burián László [2016b]: A vissza- és továbbutalás (renvoi) In: Berke Barna - Nemessányi Zoltán (szerk.): Az új nemzetközi magánjogi törvény alapjai - Kodifikációs elötanulmányok I. Budapest, HvgOrac.

Burián László [2014a]: Nemzetközi magánjog. Általános rész. Budapest, Pázmány Press.

Burián László [2014b]: A csalárd kapcsolás a tagállami - és az uniós nemzetközi magánjogban. In: Fekete Balázs - Horváthy Balázs - Kreisz Brigitta (szerk.): A világ mi magunk vagyunk. Liber Amicorum Imre Vörös. HvgOrac, Budapest.

Mádl Ferenc - Vékás Lajos [2015]: Nemzetközi magánjog és nemzetközi gazdasági kapcsolatok joga. ELTE Eötvös Kiadó, Budapest, 2015.

Raffai Katalin [2016a]: A közrendi klauzula a nemzetközi magánjogi törvényerejű rendeletben és javaslatok a hatályos szabályozás átalakítására. In: Berke Barna - Nemessányi Zoltán (szerk.) Az új nemzetközi magánjogi törvény alapjai - Kodifikációs előtanulmányok II. Budapest, HvgOrac.

Raffai Katalin [2016b]: Néhány gondolat az imperatív normák szabályozásának szükségszerüségéröl. In: Berke Barna - Nemessányi Zoltán (szerk.): Az új nemzetközi magánjogi törvény alapjai Kodifikációs elötanulmányok II. Budapest, HvgOrac.

Raffai Katalin [2016c]: Az ember személyes jogára vonatkozó szabályok a nemzetközi magánjogi törvényerejü rendeletben és javaslatok a hatályos szabályozás átalakítására. In: Berke Barna - Nemessányi Zoltán (szerk.): Az új nemzetközi magánjogi törvény alapjai - Kodifikációs előtanulmányok II. Budapest, HvgOrac.

Szabó Sarolta [2016]: A külföldi jog alkalmazásának (tartalma megállapításának) problematikája. In: Berke Barna - Nemessányi Zoltán (szerk.): Az új nemzetközi magánjogi törvény alapjai Kodifikációs előtanulmányok I. Budapest, HvgOrac.

Vékás Lajos [2016]: A törvény szerkezetéről és néhány általános részi kérdésről. In: Berke Barna - Nemessányi Zoltán (szerk.) Az új nemzetközi magánjogi törvény alapjai - Kodifikációs előtanulmányok I. Budapest, HvgOrac.

Vékás Lajos [2015]: Egy új nemzetközi magánjogi törvény megalkotásának elvi kérdéseiröl. Jogtudományi Közlöny, 2015/6. 